\title{
PAULINA MICHALSKA-GÓRECKA
}

Uniwersytet im. Adama Mickiewicza w Poznaniu

ORCID: 0000-0002-2454-0437

\section{KSZTAŁTOWANIE SIĘ POJĘĆ „DIALEKTYZM” I „REGIONALIZM” W DEFINICJACH ENCYKLOPEDYCZNYCH I SŁOWNIKOWYCH}

$\mathrm{Na}$ podstawie trwających dziesiątki lat badań, dyskusji i sporów przyjęto, że polski język literacki wykształcił się najpóźniej w XVI wieku (m.in. Urbańczyk 1953: 82-101; Kuraszkiewicz 1956: 37-96; Stieber 1956a: 97-120; Taszycki, Milewski 1956: 364-436). Za Wojciechem Ryszardem Rzepką ów rejestr polszczyzny jest w niniejszym artykule rozumiany jako:

język druków, tzn. drukowanej literatury pięknej, naukowej, użytkowej, publicystycznej, religijnej itp. i przeciwstawia się innym odmianom polszczyzny ze względu na ogólnospołeczny zasięg, najbardziej zaawansowany stopień normalizacji oraz ze względu na fakt, że polszczyzna druków poddawana była zabiegom korygującym i ujednolicającym indywidualne właściwości osobnicze języka różnych autorów również i od strony morfologicznej [...] oraz właściwości regionalne, odzwierciedla zatem oficjalną, społecznie akceptowaną normę językową tych czasów (Rzepka 1985: 24-25).

Z jednej strony więc polszczyzna doby średniopolskiej była już językiem ogólnopolskim, w znacznym stopniu jednolitym i spójnym, charakteryzującym się pierwszymi normami, wypracowywanymi przede wszystkim przez środowisko krakowskich drukarzy. Z drugiej strony zaś był to język niepozbawiony wpływu dialektów (wielkopolskiego i małopolskiego, a z czasem także mazowieckiego i kresowego), na których podłożu powstał, dlatego regionalnie nieco się od siebie różniący. W.R. Rzepka zauważa, że „regionalizacja języka narodowego przed wiekiem XIX, a zwłaszcza formującej się przez kilka stuleci polszczyzny ogólnej, zasadzała się głównie na dwu czynnikach: mało jeszcze restrykcyjnej normie oraz istnieniu stosunkowo wyraziście zarysowanych regionów (obszarów) dialektalnych, stanowiących naturalną podstawę repertuaru regionalizmów w różnych wariantach terytorialnych polszczyzny ogólnej pisanej i mówionej” (Rzepka 1993: 135).

Zdzisław Stieber traktował polszczyznę regionalną doby średniopolskiej nie jako „gwary ludowe, ale mowę polskiej «inteligencji» XVII w., tj. wykształconej części szlachty i mieszczaństwa. Był to w zasadzie ogólnopolski język literacki, mający 
jednak - różne w różnych stronach Rzeczypospolitej - dość silne zabarwienie lokalne, niewątpliwie dużo silniejsze niż mowa naszej dzisiejszej inteligencji, tak intensywnie unifikowana przez szkołę, dziennik, radio etc." (Stieber 1974: 267). W cytowanym artykule, zatytułowanym $O$ typach polszczyzny regionalnej XVII wie$k u$, autor, wskazując różnice językowe między poszczególnymi regionami, nazywa je „regionalizmami” lub „dialektyzmami”, nie definiując wprowadzonych pojęć, a nierzadko można odnieść wrażenie, że traktuje je synonimicznie. Wydaje się, że obydwa terminy Z. Stieber odnosi do znormalizowanego języka literackiego, przeciwstawiając mu nieznormalizowane gwary ludowe i stwarzając $w$ ten sposób opozycję wykształceni/niewykształceni użytkownicy języka. Nie przywołuje natomiast kryterium tekstu drukowanego.

Rozprawa Z. Stiebera, ujawniająca nieścisłości terminologiczne i/lub arbitralność terminologiczną w badaniach nad dyferencjacją regionalną polszczyzny dawnej, stała się punktem wyjścia rozważań dotyczących różnic semantycznych między pojęciami „regionalizm” i ,dialektyzm” w ujęciu diachronicznym. Niniejszy artykuł ma na celu prześledzenie ewolucji rozumienia tych dwu terminów, traktując jako materiał źródłowy słowniki i encyklopedie języka polskiego. Ekscerpcji zostały poddane zarówno prace o charakterze ogólnym: słowniki (np. Uniwersalny słownika języka polskiego pod redakcją Stanisława Dubisza) oraz encyklopedie (m.in. Wielka encyklopedia powszechna), jak i opracowania specjalistyczne: tu również słowniki (np. Stownik terminologii językoznawczej Zbigniewa Gołąba, Adama Heinza i Kazimierza Polańskiego) oraz encyklopedie (np. Encyklopedia językoznawstwa ogólnego pod redakcją K. Polańskiego). Celem artykułu jest również próba uchwycenia momentu pojawienia się analizowanych terminów w ekscerpowanych pracach, gdyż nie występują one w słownikach i encyklopediach XIX-wiecznych.

Sposoby definiowania terminu „regionalizm” w literaturze przedmiotu, a także w słownikach i encyklopediach omówiła Anna Piotrowicz w książce Typy regionalizmów leksykalnych (Piotrowicz 1991) ${ }^{1}$. Z zakresu interesujących mnie słowników i encyklopedii języka polskiego, stanowiących przedmiot analizy niniejszego artykułu, badaczka omówiła definicje zawarte w słownikach języka polskiego pod redakcją Witolda Doroszewskiego oraz Mieczysława Szymczaka, Encyklopedii wiedzy o języku polskim pod redakcją Stanisława Urbańczyka oraz wspomnianym już Słowniku terminologii językoznawczej autorstwa Z. Gołąba, A. Heinza i K. Polańskiego. A. Piotrowicz, odwołując się ponadto do Stownika terminów literackich (Michał Głowiński i in.) i przewodnika encyklopedycznego Literatura polska oraz Słownika mitów i tradycji kultury Władysława Kopalińskiego, zwróciła uwagę na obecność pojęcia „regionalizm” w innych dyscyplinach humanistycznych. Konkludując, badaczka stwierdza, że ,żadna z przytoczonych definicji nie wyczerpuje wszystkich zagadnień związanych z pojęciem regionalizmu" (Piotrowicz 1991: 14). Podobnie monografia Agnieszki Piotrowskiej-Wojaczyk zatytułowana Regionalizmy leksykalne $w$ stownikach doby nowopolskiej zawiera szczegółową część teoretyczną będącą przeglądem najważniejszych definicji terminu „regionalizm”

${ }^{1}$ Zob. podrozdz. Definicje regionalizmów w stownikach (s. 12-14) oraz Funkcjonowanie pojęcia regionalizmu w literaturze przedmiotu (s. 14-21). 
funkcjonujących przede wszystkim w literaturze przedmiotu (Piotrowska-Wojaczyk 2011)². Najnowszą pracą ukazującą mnogość definicji analizowanych pojęć, a także próbę ich rozdzielenia, jest artykuł Moniki Szymańskiej zatytułowany Regionalizmy a dialektyzmy - rozróżnienie $w$ literaturze przedmiotu $i w$ świadomości użytkowników języka (,Język Polski” 2015).

$\mathrm{Z}$ różnic językowych warunkowanych geograficznie zdawano już sobie sprawę u schyłku XV wieku - co udowadnia Mirosława Białoskórska (Białoskórska 1993: 122). Dynamiczny rozwój piśmiennictwa narodowego w dobie średniopolskiej przynosi dalsze uwagi na ten temat, pokazujące, że ówcześni użytkownicy języka dostrzegali zarówno regiony odróżniające się językowo (Kuraszkiewicz 1986: 395), jak i konkretne, wyraziste właściwości językowe różnicujące poszczególne prowincje państwa polskiego (Zwoliński 1988: 77). M. Białoskórska zauważa, że „w pierwszej fazie kształtowania się polszczyzny literackiej (XVI-XVII w.) nie różnicowało się cech regionalnych i dialektalnych w języku" (Białoskórska 1993: 131). W.R. Rzepka wniosek ten rozciąga także na wiek kolejny, gdy stwierdza, że „W oświeceniu nie istniało chyba jeszcze wyraźne odróżnienie dialektyzmów od regionalizmów, istniała raczej świadomość co do ich nosicieli i zakresu występowania (język gminu, pospólstwa, styl pospolity)" (Rzepka 1993: 142).

Zmianę w sposobie postrzegania różnic językowych uwarunkowanych regionalnie przynosi wiek XIX. Dzieje się to jednocześnie na dwu płaszczyznach. Pierwszą płaszczyznę stanowi literatura piękna i twórczość romantyków, W.R. Rzepka podkreśla zwłaszcza rolę Adama Mickiewicza, który w tekście $O$ krytykach i recenzentach warszawskich z 1828 roku nie tylko przyznaje się do stosowania prowincjonalizmów, ale podaje $\mathrm{w}$ nim także jedną $\mathrm{z}$ pierwszych definicji tego terminu: „prowincjonalizmów, to jest wyrazów i wyrażeń od ogólnie przyjętego książkowego stylu różniących się"3 (Mickiewicz 1955: V, 257; zob. Rzepka 1993: 142). Drugą płaszczyznę stanowi XIX-wieczny rozwój językoznawstwa jako dyscypliny naukowej na ziemiach polskich. Teoretyczne ujęcie problemu zróżnicowania geograficznego przynosi książka Józefa Franciszka Królikowskiego z roku 1826 zatytułowana Proste zasady stylu polskiego..., w której autor - m.in. doktor filozofii i nauczyciel, jak wynika z okładki dzieła - „wyrazy, które nie powszechnie, ale tylko pojedynczym osobom, jednej prowincyi, jednemu dyalektowi są właściwe" nazywa „prowincyalizmami” (Królikowski 1926: 46) i „przeciwstawia je zbędnym barbaryzmom, słowom podejrzanym (nowo ukutym, a zwyczajem nie rozpowszechnionym), wyrazom przestarzałym" (Piotrowicz 1991: 14). J.F. Królikowski podaje też kilkadziesiąt przykładów prowincjonalizmów, zestawiając je z wyrazami bądź

${ }^{2}$ Zob. rozdz. 3: „Regionalizm leksykalny” z perspektywy leksykograficznej-ustalenia definicyjne, s. $14-30$.

3 ,oskarżono mnie głównie o psucie stylu polskiego wprowadzeniem prowincjonalizmów i wyrazów obcych. Wyznaję, że nie tylko nie strzegę się prowincjonalizmów, ale może umyślnie ich używam. Prosiłbym zwrócić uwagę na różne rodzaje poezji w dziełach moich zawarte i każdego z nich styl podług innych sądzić prawideł. W balladach, pieśniach i w ogólności we wszelkich poezjach na gminnym podaniu opartych i szczególny charakter miejscowy noszących, wielcy poeci starożytni i nowocześni używali i używają prowincjonalizmów, to jest wyrazów i wyrażeń od ogólnie przyjętego książkowego stylu różniących się" (Mickiewicz 1955: V, 256-257). 
wyrażeniami w jego opinii „znanymi powszechnie”, np.: chyżnik-chałupnik, ciepać - rzucać, cuda pachać - figle stroić, gbur - chłop, gwara - mowa (Królikowski 1826: 46-47). Pierwsza połowa tego stulecia przynosi więc zarówno dowód na świadome używanie prowincjonalizmów w języku artystycznym, jak i dwie definicje prowincjonalizmów, rozumianych jako elementy językowe ograniczone terytorialnie. Definicje te mają charakter bardzo ogólny, ale na podstawie tekstów źródłowych W.R. Rzepka dochodzi do wniosku, że A. Mickiewicz stosował raczej regionalizmy lub kolokwializmy niż dialektyzmy (Rzepka 1993: 142).

Pojęcia „,regionalizm” i „dialektyzm” pojawiają się dopiero w XX wieku. Powstające w XIX wieku leksykony zawierają jedynie synonimiczne względem siebie hasła ,dialekt” i ,narzecze”.

Termin ,dialekt” pojawia się w omówionych słownikach i encyklopediach jako polski odpowiednik greckiego słowa diálektos, rozumianego jako ,język ludności jakiegoś regionu, pod względem kulturalno-politycznym podrzędny w stosunku do języka narodowego; gwara" (SWO 1980: 150-151). Wymiennie pojawia się w tym znaczeniu termin „narzecze”, będący XIX-wiecznym zapożyczeniem rosyjskiego naréčie 'dialekt'. Choć Wiesław Boryś znaczenie „regionalna odmiana języka, też dialekt, gwara" odnosi dopiero do wieku XX, dla XIX rezerwując znaczenie ogólniejsze - ,język, mowa", analizowane definicje potwierdzają wcześniejsze pojawienie się współczesnego znaczenia (Boryś 2005: 352). Pierwszy w dziejach polskiej leksykografii słownik etymologiczny - autorstwa Aleksandra Brücknera, wydany w latach 20. XX wieku - odnotowuje już termin „narzecze”. Wyraz ten A. Brückner uznaje za nowy, książkowy i traktuje jako synonim zadomowionego już, gdyż używanego w tym znaczeniu od XVI wieku, terminu ,gwara” (Brückner 1927/1957: 356-357).

XIX-wieczny leksykograf Samuel Bogumił Linde w swym Słowniku języka polskiego pod hasłem „dyalekt” objaśnia, że jest to „własność ięzyków; iako w naszym ięzyku Słowackim, inaczéj mówi Polak, inaczéj Rusin, inaczéj Czech, inaczéj Jlliryk, a wzdy iednak ieden ięzyk iest: tylko, iż każda ziemia ma swą własność, i także też i w Greckim ięzyku było" (Linde 1807: I, 568). S.B. Linde zróżnicowanie geograficzne odnosi nie do polskiego obszaru językowego, a do słowiańszczyzny. Definicja słownikarza wydaje się dowodem postrzegania (pod wpływem zróżnicowania języka starogreckiego i podrzędności jego regionalnych odmian wobec koiné) słowiańskiej grupy językowej jako jednego języka różniącego się lokalnie. Definicję tę można też rozpatrywać szerzej, w kontekście działalności słowianofilskiej leksykografa (zob. Lewaszkiewicz 1980).

W powstałym 50 lat później tzw. Słowniku wileńskim pod hasłem „dialekt” znajduje się odniesienie do nowego terminu, jakim było „narzecze”, rozumianego jako „sposób mówienia miejscowości jakiéj właściwy, wyróżniający się czémś od ogólnéj narodowéj mowy, wszkaże od niéj pochodzący" (SWil 1861: I, 734), wskazując na podrzędny, ale też wtórny charakter narzecza wobec języka ogólnego.

${ }^{4}$ Do analogicznego wniosku dochodzi A. Piotrowicz, analizując literaturę przedmiotu: „Dopiero w powojennej literaturze przedmiotu regionalizm, prowincjonalizm i dialektyzm zaczynają funkcjonować jako terminy, choć nie zawsze ustala się ich ścisłe definicje" (Piotrowicz 1991: 15). 
Pochodzący z przełomu XIX i XX wieku Słownik języka polskiego autorstwa Jana Karłowicza, Adama Kryńskiego i Władysława Niedźwiedzkiego „djalektem” nazywa ,język właściwy pewnej miejscowości danego kraju” (SJP 1900/1952: I, 457). Podane jako synonim „narzecze” opatrzono przykładami: narzecze kaszubskie, zakopiańskie, podlaskie (SJP 1904/1952: III, 154). Definicja nie różni się zasadniczo od wyjaśnienia zawartego w Słowniku wileńskim, nie porusza jednak problemu relacji dialekt - język ogólny. Jako synonim został w niej wymieniony nie tylko termin „narzecze”, ale i ,gwara”.

Ukazująca się od końca XIX wieku encyklopedia Samuela Orgelbranda zawiera hasło ,dialekt”, a przy nim odsyłacz do hasła „,narzecze”, w którym czytamy:

narzecze lub djalekt, jest odmianą ogólnego języka narodowego. Każdy język dzieli się na liczne narzecza. Odmianę języka ogólnego, używaną w pewnej miejscowości i charakteryzującą tę miejscowość pod względem językowym, nazywamy podrzeczem, narzeczem zaś zbiór pewnej liczby podrzeczy, różniących się widocznie od grupy sąsiednich podrzeczy. Podrzecze jest tedy idealnem zjednoczeniem mowy pojedynczych jednostek, tak samo jak narzecze jest zjednoczeniem podrzeczy, język zaś narzeczy. Język narodowy wtedy może być dokładnie scharakteryzowany, jeżeli zbierzemy i zestawimy cechy składających go narzeczy. Niema pewnych, ścisłych granic pomiędzy podrzeczem a narzeczem, oraz między narzeczem a językiem. Wyrobiony z biegiem czasu język książkowy jest także narzeczem języka narodowego, czasem sztucznie urobionem, np. język książkowy rosyjski [...]. Mylnem jest uważać narzecza za wyrodzenie się języka ogólnego, częstokroć bowiem zachowały one nierównie dawniejsze formy i inne objawy językowe. Narzecze od języka książkowego różni się głównie tem, że będąc wyłączone od literatury naukowej i poetycznej, zasobem swych wyrazów wystarcza tylko ścieśnionemu kółku codziennych potrzeb; nadto przez nieużywanie pisma zatracił wiele form, przechowywanych w języku książkowym (Orgelbrand 1901: 417).

Definicja, choć długa, została zacytowana niemal w całości, by ukazać tok wywodu charakterystyczny dla haseł encyklopedycznych tamtego okresu. W definicji S. Orgelbranda, podobnie jak w Słowniku wileńskim, została podjęta próba objaśnienia relacji narzecza wobec podrzecza z jednej i języka ogólnego z drugiej strony. Termin ten rozumiany jest szeroko, jako rejestr podrzędny wobec języka ogólnego, ale niekoniecznie ograniczony terytorialnie, gdyż za narzecze uważa się również język książkowy. Interesujące wydaje się zwrócenie uwagi na wartość narzecza jako rezerwuaru form archaicznych i na jego ograniczone zastosowanie, nieoceniane jednakże negatywnie.

W starszej, ukazującej się od schyłku lat 50. XIX wieku, wersji encyklopedii S. Orgelbranda termin ,dialekt” / „narzecze” nie został uwzględniony. Kilka dekad późniejsza od dzieła S. Orgelbranda Encyklopedia powszechna Ultima Thule Stanisława Franciszka Michalskiego wciąż zawiera jedynie hasło „narzecze” („dialekt”), tłumaczone jako:

forma szczególna, jaką niekiedy przybiera język na pewnym określonym obszarze. Na obszarze takim istnieje szereg właściwości językowych, których zespół może nadawać mowie charakter odrębny od mowy sąsiednich obszarów pomimo łączącego je pokrewieństwa. Choć narzecze często bywa utożsamiane $\mathrm{z}$ gwarą [...], termin narzecze odnosimy zazwyczaj do większych obszarów i do zmian mowy głębiej sięgających; termin gwara odnosi się wówczas do lokalnych form mowy (Encyklopedia 1935: VII, 566). 
Narzecze jest w niej odnoszone nie do języka ogólnego, a do gwary i traktowane jako nadrzędne wobec niej.

$Z$ jednej strony obydwie przywołane encyklopedie są pracami o charakterze ogólniejszym niż słowniki języka polskiego, z drugiej zaś zawierają bardziej rozbudowane i szczegółowsze artykuły hasłowe dotyczące analizowanych pojęć. Choć definicje te dzielą od siebie trzy dekady, widać, że koncentrują się one na podobnych aspektach zagadnienia. Ich autorzy charakteryzują narzecze jako mowę właściwą danemu obszarowi oraz próbują określić stosunek narzecza / dialektu do gwary / podrzecza i języka ogólnego. Definicja S. Orgelbranda wskazuje ponadto na zależność języka książkowego od narzecza, uznając język książkowy za twór będący kolejnym etapem rozwoju narzecza, charakteryzującym się większą obfitością form i zdolnym obsłużyć wszystkie dziedziny życia. S. Orgelbrand wyraża także postulat nietraktowania narzecza jako gorszego wariantu języka ogólnego, chociażby ze względu na zachowane w nim formy archaiczne. Bardzo bliskie współczesnej myśli dialektologicznej wydaje się natomiast twierdzenie S.F. Michalskiego, iż narzecze (utożsamione, jak we wcześniej omówionych leksykonach - z dialektem) tym różni się od gwary, że odnosi się do większego obszaru i do zmian językowych głębiej sięgających.

Opracowany przez Tadeusza Lehra-Spławińskiego Słownik języka polskiego Trzaski, Everta i Michalskiego notuje zarówno hasło „dialekt”, rozumiane jako „lokalna lub społeczna odmiana językowa" (Lehr-Spławiński 1939: I, 558), jak i hasło „narzecze”, objaśniane jako „lokalna odmiana języka, wykazująca pewne różnice przy zachowaniu zasadniczych cech właściwych całemu obszarowi tego języka" (Lehr-Spławiński 1939: II, 461). Nowością w stosunku do omówionych definicji jest zwrócenie uwagi autorów nie tylko na regionalne - poziome zróżnicowanie polszczyzny, ale także na jej zróżnicowanie społeczne - pionowe.

Dopiero pochodzący z przełomu lat 50. i 60. XX wieku Słownik języka polskiego pod redakcją Witolda Doroszewskiego zawiera obydwa analizowane pojęcia. Pojawienie się ich w leksykografii tego czasu ma zapewne związek z rozwojem badań nad dyferencjacją geograficzną polszczyzny po II wojnie światowej, uprawianych w ramach dialektologii i dialektologii historycznej, i działalnością takich badaczy, jak np. Kazimierz Nitsch, Władysław Kraszkiewicz, Zdzisław Stieber czy Witold Taszycki (por. m.in.: Kuraszkiewicz 1954 i 1963; Stieber 1956b; Nitsch 1958; Taszycki 1961; Sławski 1962). Nie bez znaczenia są z pewnością przedwojenne badania terenowe samego leksykografa, który - według Stanisława Urbańczyka - „podjął próbę stworzenia nowej dialektologii”, miała ona polegać m.in. na „statystycznym ujmowaniu zjawisk językowych” (Urbańczyk 1993: 243), do czego niezbędne było ścisłe rozróżnienie dwóch podstawowych terminów. Hasło „,dialektyzm” tłumaczone jest w tym słowniku jako „wyraz, forma, zwrot właściwy gwarze" (Doroszewski [red.] 1960: II, 128) i po raz pierwszy zostało opatrzone kwalifikatorem jęz. (wszystkie kolejne omawiane definicje także będą już nim poprzedzone). W obrębie dialektyzmów wydzielone zostały dialektyzmy fonetyczne, morfologiczne, syntaktyczne, leksykalne, frazeologiczne i semantyczne. „Regionalizm” natomiast definiowany jest jako ,cecha wymowy, forma gramatyczna, wyraz lub konstrukcja składniowa właściwa mowie pewnego regionu (pewnej okolicy) kraju, niekiedy upowszechniona w języku ogólnym” (Doroszewski [red.] 1965: 
VII, 887). Przykład takiego przenikania do języka ogólnego stanowią według W. Doroszewskiego podhalańskie leksemy juhas i baca. W. Doroszewski zatem nie tylko pierwszy wprowadza obydwa terminy, ale też od razu dość klarownie je rozdziela, ukazując regionalizm jako dynamiczny element języka.

Wydana dwa lata później Wielka encyklopedia powszechna notuje jedynie hasło „regionalizm” rozumiane jako:

cecha fonetyczna, forma gramatyczna, wyraz, znaczenie wyrazu lub konstrukcja składniowa, właściwe mowie pewnego regionu; regionalizm występuje w mowie potocznej środowisk wykształconych, posługujących się językiem ogólnym, literackim, nie należy ich uważać za błędy, gdyż mają oparcie w powszechnym zwyczaju językowym tych środowisk; jako synonimiczny do terminu 'regionalizm' bywa używany (niekiedy w zabarwieniu ujemnym) termin 'prowincjonalizm' (Wielka encyklopedia 1967: 746).

Definicja ta, poprzez określenie zasad funkcjonowania regionalizmu, który przeniknął do języka ogólnego, stanowi poniekąd rozwinięcie myśli W. Doroszewskiego dotyczącej możliwości upowszechnienia się regionalizmu w języku ogólnym. Poza tym, po raz pierwszy odnotowany został synonim tego terminu - znany już z literatury XIX-wiecznej ,prowincjonalizm” - wraz z uwzględnieniem jego pejoratywnych konotacji.

W wydanym w roku kolejnym specjalistycznym Słowniku terminologii językoznawczej objaśnienie „dialektyzmu” jako „wyraz lub forma gramatyczna przejęta z jakiegoś dialektu do języka ogólnego i odbiegająca od jego normy, np. pol. baca 'starszy pasterz owiec' z gwarowym c zamiast ogólnopolskiego cz" (STJ 1968: 128) wyraźnie nawiązuje do dwóch wyżej przytoczonych definicji, ale regionalizmu, nie dialektyzmu. Przy haśle „regionalizm” słownik odsyła do hasła „,prowincjonalizm", które rozumiane jest tu jako:

właściwość natury fonologicznej, morfologicznej, składniowej lub leksykalnej występująca tylko w części danego obszaru językowego (niekoniecznie związana z pewnym określonym dialektem terytorialnym), a użyta przez mówiącego (świadomie lub nieświadomie) - w języku ogólnym, w którym nie istnieje, np. wymowa uobraz zamiast obraz (STJ 1968: 457).

Według dwie dekady późniejszego Słownika języka polskiego pod redakcją Mieczysława Szymczaka ,dialektyzm” to „wyraz, forma gramatyczna, znaczenie, zwrot właściwy jakiemuś dialektowi (gwarze), zwłaszcza użyte w tekstach języka literackiego" (Szymczak [red.] 1995: I, 369). Podział na dialektyzmy fonetyczne, leksykalne, składniowe, słowotwórcze i znaczeniowe tym różni się od podziału dokonanego przez W. Doroszewskiego, że nie wyodrębnia podtypu frazeologicznego. Podobnie objaśnienie terminu „regionalizm” powtarza definicję zawartą w słowniku W. Doroszewskiego, tyle tylko, że nie zawiera przykładów (Szymczak [red.] 1995: III, 32).

Specjalistyczna Encyklopedia języka polskiego pod redakcją Stanisława Urbańczyka i Mariana Kucały również traktuje pojęcia „dialektyzm” i ,gwaryzm” wymiennie i tłumaczy je jako ,jakikolwiek element językowy odczuwany współcześnie przez użytkowników języka ogólnego jako należący do jednego z dialektów lub gwar tego języka, inaczej mówiąc: element języka nacechowany stylistycznie jako gwarowy” (EJP 1999: 76). Drugie znaczenie wskazuje na dialektyzmy jako ,elementy językowe 
przejęte z jakiegoś dialektu przez literacką odmianę języka ogólnego (tzw. zapożyczenia wewnętrzne) i dzięki całkowitemu przyswojeniu pozbawione już dialektalnego nacechowania stylistycznego” (EJP 1999: 76). „Regionalizmem” nazwiemy zaś „wyraz lub jakikolwiek inny element językowy (cecha wymowy, forma gramatyczna, konstrukcja składniowa) o zasięgu użycia ograniczonym do części obszaru danego języka narodowego; w przeciwieństwie do form dialektalnych i gwarowych regionalizm występuje również w mowie warstw wykształconych, np. w Warszawie mówi się «kartofle», w Krakowie - «ziemniaki», w Poznaniu «pyrki»» (EJP 1999: 318). $\mathrm{W}$ porównaniu $\mathrm{z}$ definicjami cytowanymi wcześniej novum stanowi zarówno próba określenia stosunku dialektyzmu do regionalizmu, jak i postrzeganie każdego dialektyzmu jako elementu językowego nacechowanego stylistycznie.

W Słowniku współczesnego języka polskiego pod redakcją Bogusława Dunaja „dialektyzm” zdefiniowano jako ,element językowy właściwy dialektowi użyty w tekście literackim” (Dunaj [red.] 2000: I, 171). „Regionalizm” zaś jako „wyraz, forma gramatyczna lub konstrukcja składniowa charakterystyczna dla mowy danego regionu, czasem upowszechniona w języku ogólnym” (Dunaj [red.] 2000: II, 231).

„Dialektyzm” utożsamiany jest też z ,gwaryzmem” w opracowanej przez Kazimierza Polańskiego Encyklopedii językoznawstwa ogólnego i objaśniany jako jednostka

systemu językowego (wyraz, forma, zwrot frazeologiczny) reprezentująca dialekt w stosunku do innych otaczających ją jednostek, reprezentujących język ogólny. Także jednostka języka ogólnego rozwinięta w sposób typowy dla jednego (lub kilku) z jego dialektów, np. zmazurzone dzban zamiast regularnego dżban. Rozróżnia się dialektyzmy: fonetyczne (np. mazowieckie nogamy zamiast nogami), gramatyczne (np. ciag zamiast ciagnij), leksykalne (np. gazda), frazeologiczne (np. robić precz), składniowe (np. gęsi lecieli), semantyczne (np. nazywanie taksówką każdego samochodu osobowego). Użycie dialektyzmu nie przyswojonego językowi ogólnemu jest nacechowane stylistycznie, użycie dialektyzmu przyswojonego językowi ogólnemu jest pozbawione takiego nacechowania. Użycie dialektyzmu bez poczucia jego wartości stylistycznej może być uznane za błąd językowy (EJO 1999: 120).

W definicji tej obok podziału dialektyzmów na podtypy pojawia się także egzemplifikacja każdego z nich. Dokładniej omówiona została również kwestia nacechowania stylistycznego dialektyzmu. Termin ,regionalizm”, traktowany jako synonim negatywnie kojarzącego się terminu ,,prowincjonalizm”, tłumaczony jest jako:

jednostka systemu językowego (wyraz, forma, zwrot frazeologiczny) reprezentująca terytorialną odmianę języka ogólnego w stosunku do odpowiadających jej jednostek typowych dla reszty obszaru językowego. Występując więc w języku ogólnym, w przeciwieństwie do form dialektalnych i gwarowych, regionalizmy występują także w języku ludzi wykształconych. Np. leksykalnym regionalizmem poznańskim jest wyraz tuk 'tłuszcz', gramatycznym - mazowiecki sufiks -ak- (kurczak, źrebak) w stosunku do ogólnego -ę- (kurczę, źrebię). Regionalizmy często pochodzą z gwar. Jeżeli regionalizm wciąż jest związany z dialektem, z którego pochodzi, nosi nazwę dialektyzmu. Synonimiczny termin ,prowincjonalizm” jest nacechowany ujemnie. W literaturze pięknej regionalizmy stosowane są w celach stylizacyjnych (EJO 1999: 485).

Definicja sugeruje, że „regionalizm” (,prowincjonalizm”) jest pojęciem nadrzędnym w stosunku do „dialektyzmu” (,gwaryzmu”). 
Najnowsze słowniki języka polskiego nie wnoszą nic nowego do rozumienia analizowanych terminów. Zgodnie z Nowym słownikiem języka polskiego pod redakcją Elżbiety Sobol jako „dialektyzm” traktowany jest „wyraz, forma, zwrot właściwy gwarze” (Sobol [red.] 2002: 132). „Regionalizmem” zaś nazwiemy „wyraz znany i używany tylko w pewnym regionie" (Sobol [red.] 2002: 832). Zgodnie z nieco późniejszym Uniwersalnym słownikiem języka polskiego pod redakcją Stanisława Dubisza „dialektyzm” to „wyraz, forma gramatyczna, znaczenie, zwrot właściwe jakiemuś dialektowi (gwarze), zwłaszcza użyte w tekstach artystycznych". Podział na dialektyzmy: fonetyczne, leksykalne, składniowe, słowotwórcze i znaczeniowe powiela podział zaproponowany przez Szymczaka (Dubisz [red.] 2006: I, 609). Pod hasłem „,regionalizm” czytamy, że jest to „cecha wymowy, forma gramatyczna, wyraz lub konstrukcja składniowa właściwe mowie pewnego regionu kraju, upowszechnione w języku ogólnym, prowincjonalizm” (Dubisz [red.] 2006: III, 910).

Słowniki etymologiczne, poza lakoniczną definicją ,dialektu” sformułowaną przez Andrzeja Bańkowskiego (Bańkowski 2000: I, 271), nie odnotowują analizowanych leksemów (zob. Brückner 1927/1957; Sławski 1952-1982; Długosz-Kurczabowa 2003; Boryś 2005).

Jak pokazuje przedstawiony materiał, definicje pojęć „regionalizm” i „dialektyzm" w słownikach i encyklopediach języka polskiego mogą się od siebie znacznie różnić. Wydaje się, że w miarę postępowania badań nad geograficzną dyferencjacją polszczyzny omawiane terminy powinny być definiowane w sposób coraz bardziej szczegółowy i precyzyjny. Tymczasem po okresie intensywnego rozwoju tego typu badań po II wojnie światowej, przejawiającego się pojawieniem się nowych haseł „dialektyzm” i „regionalizm” - w słowniku pod redakcją W. Doroszewskiego, a w późniejszych pracach próbami ich doprecyzowania, w ostatnim czasie leksykony właściwie jedynie powielają istniejące już definicje. Od kilku lat brak też toczącej się przez dekady na łamach słowników i encyklopedii „dyskusji” dotyczącej zdefiniowania tych tak istotnych terminów. Dyferencje w sposobie objaśniania wynikają także ze zróżnicowania materiału źródłowego. Słowniki i encyklopedie specjalistyczne - językoznawcze, dotyczą jednej dziedziny, co przekłada się (a przynajmniej powinno) na znaczny stopień uszczegółowienia definicji. Nie bez znaczenia pozostaje też fakt potencjalnego odbiorcy danego opracowania. Słowniki i encyklopedie specjalistyczne są kierowane do węższego kręgu odbiorców niż słowniki i encyklopedie o charakterze ogólnym. Sposób definiowania, a zwłaszcza szczegółowość definicji, w dużym stopniu zależą także od objętości dzieła. Dla porównania: słownik języka polskiego pod redakcją W. Doroszewskiego liczący 11 tomów najprecyzyjniej definiuje omawiane pojęcia, trzytomowy słownik pod redakcją M. Szymczaka nieznacznie modyfikuje definicje W. Doroszewskiego i nie zawiera przykładów, jednotomowy pod redakcją E. Sobol zawiera tylko skróty istniejących już definicji. Zależność ta nie stanowi jednak reguły, jedna z nowszych prac, sześciotomowy słownik pod redakcją S. Dubisza zawiera bardzo ogólne tylko objaśnienia terminów „regionalizm” i „dialektyzm”.

Liczba funkcjonujących w słownikach i encyklopediach definicji potwierdza stopień złożoności analizowanego zagadnienia. Wydaje się, że żadna z przytoczonych definicji nie wyczerpuje problemu w pełni, wobec czego badacz zajmujący się 
zagadnieniem zróżnicowania terytorialnego, zarówno w perspektywie diachronicznej, jak i synchronicznej, będzie każdorazowo zmuszony do zredefiniowania charakteryzowanych pojęć polegającego na dostosowaniu ich zakresu znaczeniowego do własnych potrzeb badawczych.

\section{Słowniki i encyklopedie objęte skrótami}

EJO - Encyklopedia językoznawstwa ogólnego, red. K. Polański, Wrocław-Warszawa-Kraków 1999.

EJP - Encyklopedia języka polskiego, red. S. Urbańczyk, M. Kucała, Wrocław-Warszawa-Kraków 1999.

SJP - J. Karłowicz, A. Kryński, W. Niedźwiedzki, Słownik języka polskiego, t. 1, Warszawa 1900/1952; t. 3, Warszawa 1904/1952.

STJ - Słownik terminologii językoznawczej, red. Z. Gołąb, A. Heinz, K. Polański, Warszawa 1968.

SWil - Stownik wileński, czyli Słownik języka polskiego, red. A. Zdanowicz i in., t. 1, Wilno 1861.

SWO - Stownik wyrazów obcych, red. J. Tokarski, Warszawa 1980.

\section{Pozostałe słowniki i encyklopedie}

Bańkowski A., 2000, Etymologiczny słownik języka polskiego, t. 1, Warszawa.

Boryś W., 2005, Słownik etymologiczny języka polskiego, Kraków.

Brückner A., 1927/1957, Stownik etymologiczny języka polskiego, Warszawa.

Długosz-Kurczabowa K., 2003, Nowy słownik etymologiczny języka polskiego, Warszawa.

Doroszewski W. (red.), 1960, 1965, Stownik języka polskiego, t. 2 i 7, Warszawa.

Dubisz S. (red.), 2006, Uniwersalny słownik języka polskiego, t. 1 i 3, wyd. 2, Warszawa.

Dunaj B. (red.), 2000, Stownik współczesnego języka polskiego, wyd. 2, t. 1 i 2, Warszawa.

Encyklopedia Powszechna Ultima Thule, 1935, red. S.F. Michalski, t. 7, Warszawa.

Lehr-Spławiński T. (oprac.), 1939, Stownik języka polskiego Trzaski, Everta i Michalskiego, t. 1-2, Warszawa.

Linde S.B., 1807, Słownik języka polskiego, t. 1, cz. 1 ( $A-F)$, Warszawa, http://kpbc.umk.pl/ dlibra/docmetadata?id=12850\&from=publication [dostęp: 15.09.2018].

Orgelbrand S., 1901, S. Orgelbranda encyklopedja powszechna z ilustracjami i mapami, t. 10, Warszawa.

Sławski F., 1952-1982, Słownik etymologiczny języka polskiego, t. 1-5, Kraków.

Sobol E. (red.), 2002, Nowy stownik języka polskiego, Warszawa.

Szymczak M. (red.), 1995, Stownik języka polskiego, t. 1 i 3, Warszawa.

Wielka encyklopedia powszechna, 1967, t. 9, Warszawa.

\section{Literatura}

Białoskórska M., 1993, Postrzeganie zróżnicowania regionalnego polszczyzny do końca XVIII wieku, w: Region, regionalizm. Pojęcia i rzeczywistość, red. K. Handke, Warszawa, s. 121-132 . 
Dejna K., 1993, Dialekty polskie, Wrocław-Warszawa-Kraków.

Królikowski J.F., 1826, Proste zasady stylu polskiego rozmaitemi postrzeżeniami względem języka, dla użytku jasno, zwięźle, poprawnie, gładko i szczerze po polsku pisać chcacych, praktycznie $w$ przyktadach okazane a wzorami rozmaitego toku i sposobu pisania..., Poznań, http://ebuw.uw.edu.pl/dlibra/docmetadata?id=4550 [dostęp: 15.09.2018].

Kuraszkiewicz W., 1954, Zarys dialektologii wschodniosłowiańskiej (wyd. 2 rozszerz. 1963).

Kuraszkiewicz W., 1956, Tło społeczne rozwoju polskiego języka literackiego, w: Z dziejów powstawania języków narodowych i literackich, red. Z. Stieber, Warszawa, s. 37-96.

Kuraszkiewicz W., 1986, Piotr Statorius-Stojeński o polskim języku literackim (,,Polonicae grammatices institutio”, 1568 r.), w: W. Kuraszkiewicz, Polski język literacki. Studia nad historia i struktura, Warszawa-Poznań 1986, s. 384-408.

Lewaszkiewicz T., 1980, Panslawistyczne osobliwości leksykalne S.B. Lindego i jego projekt stworzenia wspólnego języka słowiańskiego, Wrocław.

Mickiewicz A., 1955, O krytykach i recenzentach warszawskich, w: A. Mickiewicz, Dzieła, t. 5, Pisma proza, Warszawa, s. 255-274.

Nitsch K., 1958, Dialekty języka polskiego (wyd. poprawione), Wrocław-Kraków.

Piotrowicz A., 1991, Typy regionalizmów leksykalnych, Poznań.

Piotrowska-Wojaczyk A., 2011, Regionalizmy leksykalne w stownikach doby nowopolskiej, Poznań.

Rzepka W.R., 1985, Demorfologizacja rodzaju w liczbie mnogiej rzeczowników w polszczyźnie XVI-XVII wieku, Poznań.

Rzepka W.R., 1993, Status regionalizmów w polszczyźnie XIX wieku, w: Region, regionalizm. Pojęcia i rzeczywistość, red. K. Handke, Warszawa, s. 133-150.

Sławski F., 1962, Zarys dialektologii południowosłowiańskiej, Warszawa.

Stieber Z., 1956a, Udział poszczególnych dialektów w formowaniu polskiego języka literackiego, w: Z dziejów powstawania języków narodowych i literackich, red. Z. Stieber, Warszawa, s. $97-120$.

Stieber Z., 1956b, Zarys dialektologii języków zachodniosłowiańskich z wyborem tekstów gwarowych, Warszawa.

Stieber Z., 1974, O typach polszczyzny regionalnej XVII wieku, w: Z. Stieber, Świat językowy Stowian, Warszawa, s. 267-272.

Szymańska M., 2015, Regionalizmy a dialektyzmy - rozróżnienie $w$ literaturze przedmiotu $i$ świadomości użytkowników języka, „Język Polski” 95, s. 366-376.

Taszycki W., 1961, Dialektologia historyczna i problem pochodzenia polskiego języka literackiego, Wrocław.

Taszycki W., Milewski T., 1956, Polski język literacki powstał w Małopolsce. Głos w dyskusji nad pochodzeniem literackiej polszczyzny, w: Pochodzenie polskiego języka literackiego, red. K. Budzyk, Wrocław, s. 364-436.

Urbańczyk S., 1953, Głos w dyskusji o pochodzeniu polskiego języka literackiego, w: Pochodzenie polskiego języka literackiego, red. K. Budzyk, Wrocław 1956, s. 82-101.

Urbańczyk S., 1993, Dwieście lat polskiego językoznawstwa (1751-1950), Kraków.

Zwoliński P., 1988, Wypowiedzi gramatyków XVI i XVII wieku o dialektyzmach w ówczesnej polszczyźnie, w: P. Zwoliński, Szkice i studia z historii slawistyki, Wrocław-Warszawa-Kraków, s. 67-99. 


\title{
PAULINA MICHALSKA-GÓRECKA
}

\section{The emergence of concepts of "dialectism" and "regionalism" in encyclopaedias and dictionaries}

\begin{abstract}
Summary
The goal of this article is to trace the evolution of understanding two basic concepts in linguistics, namely "dialectism" and "regionalism" with Polish dictionaries and encyclopaedias as the source materials. Excerpts from both general and highly specialised texts have been made. The presented material shows that the definitions of the analysed concepts may vary significantly from one Polish dictionary or encyclopaedia to another. It seems that neither of the definitions exhausts the issue therefore a researcher in charge of territorial differences, in a diachronic and synchronic perspective alike, will have to re-define each time the characterised concepts by means of adjusting their meaning-related scope to his or her own research needs.
\end{abstract}

Keywords: dialectism, regionalism, territorial differences 